\title{
Knowledge of managers on the National Mental Health Policy
}

\author{
Conhecimento de gestores sobre a Política Nacional de Saúde Mental \\ Conocimiento de los gestores respecto de la Política Nacional de Salud Mental
}

Rafaella Leite Fernandes'
ORCID: 0000-0001-5269-1702

Francisco Arnoldo Nunes de Miranda'

ORCID: 0000-0002-8648-811X

Kalyane Kelly Duarte de Oliveira" ORCID: 0000-0001-7713-3264

Clara Tavares Rangel' ORCID: 0000-0002-8403-0025

Danyella Augusto Rosendo da Silva Costa' ORCID: 0000-0002-6765-6472

Izabella Bezerra de Lima Moura' ORCID: 0000-0003-4959-7525

'Universidade Federal do Rio Grande do Norte. Natal, Rio Grande do Norte, Brazil. "Universidade Estadual do Rio Grande do Norte. Mossoró, Rio Grande do Norte, Brazil.

How to cite this article: Fernandes RL, Miranda FAN, Oliveira KKD, Rangel CT, Costa DARS, Moura IBL. Knowledge of managers on the National Mental Health Policy.

Rev Bras Enferm. 2020;73(1):e20180198. doi: http://dx.doi.org/10.1590/0034-7167-2018-0198

Corresponding Author:

Izabella Bezerra de Lima Moura

E-mail: bellalimash@gmail.com

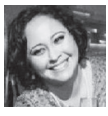

EDITOR IN CHIEF: Antonio José de Almeida Filho ASSOCIATE EDITOR: Fátima Helena Espírito Santo

Submission: 03-21-2018

Approval: 07-27-2018

\section{ABSTRACT}

Objective: Identify the knowledge of mental health service managers about the national mental health policy. Method: This is a qualitative study conducted with 20 coordinators, who were submitted to a structured interview. Data were categorized in a thematic analysis using ALCESTE software. Results: The results produced the following categories: Back to society: protagonism and autonomy of patients; Interprofessional team: assignments and activities; Structuring of a psychosocial care network; Challenges affecting the service; Distance between policy and practice. Final Considerations: Public managers demonstrated they are aware of the key concepts for effective structuring of a psychosocial care network based on patient protagonism and autonomy, the assignments and activities performed by interprofessional teams, and the challenges found while structuring a psychosocial care network.

Descriptors: Mental Health; Mental Health Services; Health Workforce; Health Managers; Nursing Research.

\section{RESUMO}

Objetivo: Identificar o conhecimento dos gestores de serviços de saúde mental sobre a política nacional de saúde mental. Método: Trata-se de uma pesquisa qualitativa realizada com 20 coordenadores, submetidos à entrevista estruturada. Os dados foram categorizados sob a análise temática, auxiliada pelo software ALCESTE. Resultados: Os resultados apontaram as seguintes categorias: De volta à sociedade: protagonismo e autonomia dos usuários; Equipe multiprofissional: atribuições e atividades; Estruturação da Rede de Atenção Psicossocial; Entraves que afetam o serviço; Distanciamento entre a política e a prática. Considerações Finais: Os gestores demonstraram conhecimento sobre os conceitos-chave para a efetiva construção da rede de atenção psicossocial a partir do protagonismo e autonomia dos usuários, das atribuições e atividades desempenhadas pela equipe multiprofissional, e das dificuldades em estruturar a rede de atenção psicossocial.

Descritores: Saúde Mental; Serviços de Saúde Mental; Recursos Humanos em Saúde; Gestores de Saúde; Pesquisa em Enfermagem.

\section{RESUMEN}

Objetivo: Verificar el conocimiento de los gestores de servicios de salud mental acerca de la política nacional de salud mental. Método: Investigación cualitativa, realizada con 20 coordinadores, sometidos a entrevista estructurada. Datos categorizados de acuerdo a análisis temático, con ayuda del software ALCESTE. Resultados: Los resultados determinaron las siguientes categorías: De vuelta a la sociedad: protagonismo y autonomía de los pacientes; Equipo multiprofesional: atribuciones y actividades; Estructuración de la Red de Atención Psicosocial: Trabas que afectan el servicio; Distancia entre la política y la práctica. Consideraciones Finales: Los gestores demostraron conocimientos sobre los conceptos clave para la efectiva construcción de la red de atención psicosocial a partir del protagonismo y la autonomía de los pacientes, de las atribuciones y actividades desempeñadas por el equipo multiprofesional, y de las dificultades para estructurar la red de atención psicosocial. Descriptores: Salud Mental; Servicios de Salud Mental; Fuerza Laboral en Salud; Gestores de Salud; Investigación en Enfermería. 


\section{INTRODUCTION}

More than ten years after the approval of Law 10.216/2001(1) that regulates mental health services in Brazil, the National Mental Health Policy (PNSM - Política Nacional de Saúde Mental) in force in the country should be understood considering the contexts of care services and the system that manages these policies, with a focus on psychosocial care and structuring of a care network.

The PNSM is a result of the deinstitutionalization process of psychiatric care for the implementation and expansion of a network of substitute care services, with an increasing number of Psychosocial Care Centers (CAPS - Centros de Atenção Psicossocial) and a considerable reduction in the number of beds in psychiatric hospitals across the country ${ }^{(2)}$.

In 2011, the Psychosocial Care Network (RAPS - Rede de Atenção Psicossocial) was created in Brazil through legal and normative instruments to increase population access to psychosocial care and ensure a coordination among mental health care sites, which include CAPS, clinics, therapy homes, beds in general hospitals, among other sites that support resocialization and reintegration of individuals into the community ${ }^{(3-4)}$.

Regardless of the quantitative effect of services, there is a fragile articulation with community services and lack of equipment in the mental health care network ${ }^{(5)}$. Besides these factors, the services and care provided to users are unsatisfactory, demonstrating network weakening; despite a recognition of process implementation, the current needs of mental health care should be urgently fulfilled due to crisis situations of patients and the increasing number of users of crack cocaine and other drugs, both requiring effective and efficient actions $s^{(4)}$.

The moment of transition is complex due to its singular process as it ensures extramural therapy actions, leading to reorganization of work processes, roles and responsibilities through an articulation of multiple actors and services involved in RAPS, and demanding from professionals a comprehensive view of political and social aspects combined with a theoretical foundation to guide their practice ${ }^{(5-8)}$.

Considering the above, the following study question was formulated: What is the knowledge on the National Mental Health Policy of mental health service coordinators from municipalities in the state Rio Grande do Norte?

\section{OBJECTIVE}

Identify the knowledge of mental health service managers about the National Mental Health Policy.

\section{METHOD}

\section{Ethical aspects}

This study is part of the project "Roles and responsibilities of mental health professionals and policies in the state of Rio Grande do Norte," submitted to and approved by the Research Ethics Committee of the Federal University of Rio Grande do Norte (CEP/UFRN).

This study also had the approval of the Mental Health Coordination of the state of Rio Grande do Norte and the Health
Departments from all 27 municipalities in the state with a psychosocial care center.

\section{Study type}

This is a qualitative descriptive study based on a doctoral thesis produced for a graduate program in nursing at the Federal University of Rio Grande do Norte (UFRN).

\section{Study setting}

This study was conducted in the CAPS in the interior of the state of Rio Grande do Norte (RN). The RAPS of Rio Grande do Norte has 29 CAPS, distributed into eight health regions.

\section{Source of data}

This study included 19 municipalities which are related to problems addressed by the RAPS. Data were collected from the state coordinator of the Psychosocial Care Network and all 19 municipal mental health coordinators of the municipalities of the state of Rio Grande do Norte that comprise the RAPS, totaling 20 participants.

After the participants signed an informed consent form, they were individually submitted to structured interviews with 10 open-ended questions about their knowledge about mental health priorities of current policies politics, structure of mental health services in the current care system, the responsibilities of professionals in mental health services, and challenges that affect these services, among other topics.

This study included all professionals who fulfilled the criteria of being health care technicians. Professionals on vacation or medical leave were excluded.

\section{Data collection and organization}

Data were collected from August to October 2014.

\section{Data analysis}

The information obtained in these interviews was recorded using an electronic recorder, and then transcribed and converted into a corpus format for processing in the ALCESTE software (Analyse Lexicale par Contexte d'un Ensemble de Segment de Texte, in French) and submitted to thematic analysis ${ }^{(9)}$.

The analysis procedure for the creation of meaningful categories had three stages: 1- pre-analysis, with the organization and reading of all transcriptions, and corpus organization; 2- exploration of the material after processing in ALCESTE, with coding and grouping of statements according to similarities of meaning; 3 - analysis and interpretation of results, generating categories of discussion ${ }^{(9)}$.

\section{RESULTS}

ALCESTE generated seven classes, after an initial reading process and successive re-readings for the identification of meanings to produce categories of analysis related to the knowledge of managers about the PNSM/RAPS. As a result, five categories were 
defined: Back to society: Protagonism and autonomy of patients; Interprofessional team: assignments and activities; Structure of a psychosocial care network; Challenges affecting the service; Distance between policy and practice.

For a better visualization of the articulation between the classes of ALCESTE and the thematic categories, all data will be discussed in the results based on the literature on the subject, where the speeches of participants were identified according to the format and identification of the variables and subjects used in ALCESTE, for instance: (*subject_01), and so on, for all study interviewees.

\section{Back to society: Protagonism and autonomy of patients}

Mental health coordinators from the municipalities analyzed in this study showed actions and measures to encourage the autonomy of patients that received care, placing them as protagonists of their treatment, fulfilling the requirements of the psychosocial care model.

The examples mentioned by the interviewees are related to the process of reintegration into society, the importance of receiving patients, the openness and freedom offered by the services, methods of income generation, and promotion of patient resocialization process and autonomy.

[...] we have many good examples, [...] we have a family under treatment here, a couple who was living on the street and who lost custody of their six children for using crack cocaine and, in less than eight months attending the CAPS, we've already managed with the Guardianship Council to have three children back with them, they already regained the custody of three children and are living in a small house they got through social actions, both of them are in controlled abstinence, one is already back to work and [...] they are returning to society. This reinsertion is a motivation for us and for those who are here, to show that it is possible. (*subject_11)

[...] our goal here, first, would be receiving the patient and then offering a decent treatment, make patients understand their rights, understand they can be in the community without going to a psychiatric hospital, and the second point would be patient resocialization, empowering them to return to their life considering their limitations [...]. (*subject_15)

[...] so we can offer them extra skills so, when they leave here, for reinsertion in society, they will have something to offer to support them, their life, their families; then we develop therapies here, crafts with recycled products to generate income for them. (*subject_19)

This door is symbolically closed, [...] it is open to anyone who wants to enter at any time they think they need to get support. (*subject_11)

\section{Interprofessional team: Assignments and activities}

Managers must know the assignments of each member of the mental health team, and based on this understanding, the number and the individual and collective assignments of the teams were described according to the reality of the municipalities.

We have in our center one psychiatrist, one nurse, two psychologists, two social workers, one pharmacist, two nursing technicians, one pharmacy technician, one music technician, two administrative/ SAME professionals and one cook. (*subject_03)

The speeches of the managers and the state coordinator show some knowledge about the development of activities shared or jointly performed by some professionals, and common individual activities to everyone or specific activities of each professional category, such as a physician, as indicated below:

[...] there's another activity in which the team works together: the workshop [...]. (*subject_07)

[...] all professionals who perform group activities [...] also perform individual listening [...]. (*subject_15)

[...] the psychiatrist provides individual care in consultations, and provides prescriptions, statements, changes medication. (*subject_17)

Lack of knowledge of managers, as indicated in the following speech, shows positioning based on "guessing" and individual interpretations of every professional, generating noncompliance with ministerial regulations of the Health Promotion Network (RPS - Rede de Promoção à Saúde):

I wouldn't say the diagnosis is provided by the physician, I guess it's provided by the team. I think the diagnosis should be provided by the team after a collective discussion. (*subject_01)

So we had this gap, we didn't know how to define assignments for that, we were all doing it together, so it was analyzed, and assignments were defined for everyone and discussed with each professional matching one's area because we had to adapt it to our reality. ( ${ }^{*}$ subject_14)

\section{Structure of a psychosocial care network}

In response to the structure of the psychosocial care network, most managers highlighted the flow of the services available in the state and their work objective.

Today the policy is RAPS, which is a group of sectors comprising this network [...] trying to structure [...] to provide outpatient, emergency and urgent care, [...] home care, [...]. (*subject_06)

[...] articulating basic, emergency and urgent care, beds in a general hospital, psychosocial care services [CAPS], then the idea, in this network structure, is to articulate these services so they work better to minimize these gaps in care. (*subject_01)

The current care model adopted by the Ministry of Health prioritizes de-hospitalization and psychosocial rehabilitation in psychosocial care centers [...]. (*subject_05)

\section{Challenges affecting the service}

The managers reported the following main obstacles: structural problems of the services, in many cases with insufficient physical space to perform the activities; lack of mental health training of professionals working in the services and lack of permanent 
education; poor articulation of the psychosocial care network; and stigma as an obstacle to resocialization of CAPS patients.

[...] we can't work well in this place. It doesn't offer a good structure for the service. It's a small place, the number of professionals is also small, so because of these factors, the service is not doing very well. (*subject_10)

[...] professionals who arrived here, they had no training, we have very few resources, we don't have another solution, we don't have proposals at the state level that can ensure training. (*subject_14)

[...] then our biggest obstacle is financial, another very important obstacle is our networks that don't work, our center is a supporting hospital, [...] they are not responsible for the patients who go there, so they call the CAPS and we can't find a way to handle it. (*subject_15)

Well, I think, I think prejudice, stigma, at least I see it a lot. We can go up to a certain level, I realize that when you address the problem of a drug user, you even see a good progress of that patient, but then, when you start the process of reintegration, [...] society is not ready, you can't find a job for a person in treatment, who is in a CAPS. The fact that this person attends a CAPS, many people say "oh, he or she is mad". (*subject_18)

\section{Distance between policy and practice}

The participants showed a general opinion of a distance between the mental health policy and legislation in force in the country and the daily experience of professionals, a process of transition between what was in force before and what came into effect with the mental health policies.

Sometimes what's written in the paper, in the legislation, in the policy, is not what happens in practice. Practice is often very different from the policy that was proposed, so I still see a very big gap. (*subject_06)

I see distance and no interaction between legislation and policies and the practice at the moment of transition, because reality, the experience of mental health, needs more support, hospital-centric deinstitutionalization was a big progress, but we need service and support units to patients in crisis, families need this support, professionals need support, supervision, training. ( ${ }^{*}$ subject_03)

So, the State, the Municipal Department and the State Department of Mental Health, they work on that, trying to adjust it to help reduce the number of beds, crowds, but I don't think they'll be able to do it. They won't do it until the CAPS is physically structured and with human resources, as it should be. (*subject_10)

\section{DISCUSSION}

Measures to encourage protagonism of patients treated in the services were described by the interviewees as included in the psychosocial care model. The support offered by social groups and different instruments such as the Guardianship Council and social workers is critical for social inclusion of people with mental disorders or problems related to alcohol and other drug $s^{(10)}$. Reintegration of these people into society is very important for their process of reinclusion and resocialization, placing them in a context lost in the past or never experienced by them in the community.

Successful stories can increase the self-esteem of professionals working in mental health services and can act as guidance and motivation for other patients.

Patient reception by the service team goes beyond a screening process; it is a listening process that allows more humanized and clarifying relationships with the patients ${ }^{(11)}$. Bonds strengthen the credibility of professionals, influencing the therapeutic response of mental health patients.

The process of income generation can be considered from different positive aspects in the life of mental health patients. In a study conducted with patients from mental health services inserted in income generation projects in the municipalities of the state of São Paulo, the patients reported work as a means of personal satisfaction and enabler of possibilities, a tool in the recovery process, a method to occupy the time, an enhancer of purchasing power and independence, and a driver of social relations ${ }^{(12)}$.

Although the managers indicated patient protagonism and autonomy as critical in the psychosocial care model, the results obtained from the services analyzed showed an absence of specific projects of income generation, linked or not with a solidarity economy movement or individual initiative of the services analyzed. In this sense, only specific actions and workshops are offered by some CAPS professionals, in activities that are not attractive to patients, and those who participated in these actions had a prior link with the proposed activity. This finding indicates more programs should be inserted or agreements should be made with services of the network, given the importance of work in the life of human beings for the development of territorial networks.

The participants of this study, encouraged during the structured interview, answered the questions about what technical professionals at the intermediate and higher levels comprised the teams that worked under their responsibility and the activities developed in the services. The work performed in a CAPS requires professional horizontality, including relations with patients, and the knowledge resulting from interdisciplinarity should expand the work developed by the multiprofessional team seeking to reach the goals of this service ${ }^{(13)}$.

CAPS, based on the PNSM/RAPS, should develop a multiprofessional and interdisciplinary network ${ }^{(14)}$. In this sense, health professionals (psychiatrists or mental health specialists, nurses, psychologists and technicians) have professional practice and the code of ethics that are specific to each category, which from an interdisciplinary perspective, refers to a therapeutic agenda for each service, and a singular therapeutic project.

This study showed that most participants reported the presence of minimum staff required for the service operation, according to Decree 336/2002, which sets the specifications for each type of CAPS and the number of minimum professionals to ensure the provision of services to patients ${ }^{(15)}$.

The decree does not specify the assignments of each professional category of the service, but emphasizes that everyone is involved from patient reception to discharge, thus favoring a successful reintegration of patients into social groups ${ }^{(14)}$. Based 
on the profile of the work conducted in the CAPS and from a multi- and interdisciplinary perspective, it is a facilitator of the therapeutic development process, recognizing that every professional must bring the attributions and specificities of their training technique to their practice. Thus, some activities are common to all professionals and some are specific activities performed according to the ethical and legal competence of each category.

Paradoxically, while there is no technical delimitation of the professional practice or performance, which can cause gaps, confusion or doubt among the professionals in specific assignments of each category, the isolation of medical knowledge aggravates the situation, becoming an obstacle for disciplinary interaction and exchange of knowledge and experience ${ }^{(13)}$.

The psychosocial care model that has been adopted suggests mental health should have an interdisciplinary diagnosis, considering this professional interaction as an important element of the complexity of every patient's therapeutic project ${ }^{(16)}$. However, the interviewees showed some insecurity when giving their opinion, due to limited ability and competency in the operational and doctrinal objectives of RAPS, reporting it only as personal positioning without proper conviction based on a general understanding of the health policy.

Complying with specific regulations is essential; and such requirement when selecting a manager could reduce or avoid actions and practices based on the opinion of each professional and would standardize care provided by the CAPS according to expected service.

The psychosocial care network aims to increase access of the general population to psychosocial care, connecting people with care centers and qualifying the service by providing patient reception, urgent care and continuous monitoring of patients with mental disorder or suffering and needs related to the use of crack cocaine, alcohol and other drugs, within the Unified Health System ${ }^{(4,14)}$.

In this sense, the interviewees were questioned about the priorities of mental health care in the current policy, that is, the search for fulfillment by adopting a single mission based on common goals and a cooperative and interdependent action that imply continuous care at the primary, secondary and tertiary levels ${ }^{(17)}$.

In this study, some superficiality or tangency is observed, which can also be understood as a lack of knowledge about mental health care priorities in the current care policy, restricting their focus to the existence of the CAPS as something ordinary and uncritical. Another study observed the use of disparate strategies of decentralization and regionalization, with a focus on municipalities (isolated local systems), without a regional and systemic approach, and a delayed emphasis on regionalization in the national health policy ${ }^{(18)}$.

Important issues that need to be addressed by the interdisciplinary team regarding the psychosocial practice in mental health in substitute services and that refer to the perspective of the therapeutic work and the relationship of cooperation involving the patient, family members and the community were not addressed by the interviewees ${ }^{(16)}$.

The Brazilian psychiatric reform, its policy and the proposed model of psychosocial care are in a process of metamorphosis, with ingrained practices and a hegemonic model inherited from classical psychiatry that reinforces the biomedical and medicalizing model, and on the other hand, a new and redesigned field, where several actors interact to deconstruct the inherited model and build a shared model of mental health care. Because of its psychodynamic, polysemous and complex aspect, this proposal requires a long time to be implemented, until the conceptual aspects involved can be sufficiently clear for professionals, patients, family members and managers, in constant (re)construction.

As the professionals working in mental health care face a number of challenges, the managers, considered as mental health articulators, should act as institutional supporters ${ }^{(14)}$ as well. In this sense, naturalization is observed among the practices inherited from historical processes of each profession involved in the RPS and that are confronted with legal and doctrinal aspects.

Regarding the obstacles affecting mental health services, this study observed dissatisfaction with work, in terms of a physical structure and human resources not consistent with the practice of mental health care and proposed substitute services, where subjective and singular aspects of these professionals have not been properly clarified and stated. The alienating or deficient work conditions hinder the perception of professionals as the subjects of their own work, co-responsible for quality care ${ }^{(19)}$.

Ministerial directives reinforce that CAPS can be located in the physical area of a general hospital or in a university health institution, as long as they have an independent physical structure, with private access and own staff ${ }^{(14)}$. This condition and its types of treatment do not ensure a change of logic. It was not the intramural physical structure that did not give answers to classical psychiatry, but the performance of the professionals focused on an excluding, alienating and hospital-centric model. It is a mistake to attribute the deleterious effects of psychiatry to the physical space of a hospital, considering the historical, social and political proportions of a certain period and the current social context.

Another aspect identified in this study refers to the distance between policy and practice. The political movement that originated the Brazilian Reform started with the problematization of the psychiatric hospital model and its articulation with the military regime, as this model acted as a practice of exclusion and torture of political prisoners ${ }^{(20)}$, not to mention the costs resulting from associations with hospitals, clinics, homes that adopted the hospitalization model and high investments leading to a crisis of the social security system in Brazil.

The RPS includes additional dimensions besides population, operational structure and health care model, involving the economic and social aspects of the country, facing great challenges to ensure a solidary and cooperative network of municipal and regional mental health and new ways of addressing health issues, respecting the principles of the Psychiatric Reform ${ }^{(16)}$.

Therefore, a gap is observed in the understanding of the psychiatric hospital model and its structure and method to treat madness, in general, for an open model that uses the concept of accountability, deinstitutionalization and psychosocial care among the actors involved based on a territorial dimension. In other words, when changing the confinement of the mental asylum/psychiatric hospital as a private space into an public space that is open, participatory, democratic, for citizens, as proposed by the CAPS, this movement causes some distance 
and imprecision in the understanding of policy, practice and legislation that regulates the actions of every professional in the context of psychosocial care.

In this sense, the RPS was built without hierarchy, using an endless wheel method ${ }^{(17)}$, to handle the new approaches of process management with technical support, building and strengthening dialogue, personal and affective and institutional bonds, appreciation of articulators and workers, among others ${ }^{18}$, causing this distance based on what affected the managers, workers and the work process in psychosocial care.

The managers who participated in this study reported an absence of a support besides CAPS to fulfill the demand of people with mental disorders. In many municipalities or regions, CAPS is the only mental care facility for these patients, excluding the other services that should fulfill the expectations of basic care of high complexity from the process or from the Psychosocial Attention Network. This distance or gap does not seem to recognize moments of crisis of mental and behavioral disorders, but the (re)structuring effect of RPS in the provision of services its work processes involved, in a perspective of collective production ${ }^{(13)}$.

The professionals should be aware of their participation in the mental health care process, whether in specialized services or broader clinical services, such as general hospitals and basic care (work teams and conditions). Some speeches of interviewees indicate they do not believe that mental health policies will be actually fully implemented, given the challenges found today in the support and organizational structure of RAPS.

However, reformulations of the mental health policy include a redefinition of the professionals providing care and members of a multidisciplinary team, and every actor involved in the process should develop a more inclusive service that responds more coherently to the current political and ideological principles of the PNSM ${ }^{(21)}$.

\section{Study limitations}

This study has the following limitations: the fact that it was developed in only one Brazilian state, not allowing generalization of the results; the period (year) when this study was conducted; and the current mental health policy in contrast with the psychosocial model based on the idea of returning to the psychiatric hospital model, resulting from a gap between the policies and practices of coping with drug abuse and psychosocial care practices. However, these aspects do not disqualify the study contributions, considering the evidence found and the pioneering work developed in the state regarding the theme and its challenges.

\section{Contributions to nursing, health care or public policy}

The findings provide a general view of the network of mental health services in the State of Rio Grande do Norte, with CAPS as the door and transformation from an asylum approach to a psychosocial, participatory, democratic and autonomous model. Then, further and complementary studies will have to be developed, considering these findings can be published to ensure, at first, a discussion to overcome challenges and, consequently, (re)build roles and assignments of the professionals from the multiprofessional team, where a therapeutic agenda is guaranteed, based on a singular therapeutic project, respecting the singularities of patients, family members and professionals.

\section{FINAL CONSIDERATIONS}

The managers interviewed in this study considered the policies and structure of the psychosocial care network in a conflictive or comparative way, associated with the practice in the context of the CAPS, besides some distance between what policy and practice mean in solving mental health problems in a territorial perspective.

In addition, the managers showed they have knowledge about the key concepts for the effective construction of the psychosocial care network based on patient protagonism and autonomy, the assignments and activities performed by the multiprofessional team, and the challenges found while trying to structure the psychosocial care network.

\section{REFERENCES}

1. Ministério da Saúde (BR). Lei no 10.216, de 6 de abril de 2001. Dispõe sobre a proteção e os direitos das pessoas portadoras de transtornos mentais e redireciona o modelo assistencial em saúde mental [Internet]. Brasília: Ministério da Saúde; 2001 [cited 2018 Feb 22]. Available from: http://www.planalto.gov.br/ccivil_03/leis/leis_2001/l10216.htm

2. Silva G, Iglesias A, Dalbello-Araujo M, Badaro-Moreira MI. Practices of integral health care for people with mental suffering in primary health care. Psicol Ciênc Prof. 2017;37(2):404-17. doi: 10.1590/1982-3703001452015

3. Macedo JP, Abreu MM, Fontenele MG, Dimenstein M. The regionalization of mental health and new challenges of the Psychiatric Reform in Brazil. Saúde Soc. 2017;26(1):155-70. doi: 10.1590/s0104-12902017165827

4. Ministério da Saúde (BR). Portaria n 3.088, de 23 de dezembro de 2011. Institui a Rede de Atenção Psicossocial para pessoas com sofrimento ou transtorno mental e com necessidades decorrentes do uso de crack, álcool e outras drogas, no âmbito do Sistema Único de Saúde (SUS). Brasília: Ministério da Saúde; 2011 [cited 2018 Feb 22]. Available from: http://bvsms.saude.gov.br/bvs/saudelegis/gm/2011/ prt3088_23_12_2011_rep.html

5. Perez KV, Bottega CG, Merlo ARC. Analysis of occupation health and mental health policies: a proposal of articulation. Saúde Debate. 2017;41(spe2):287-97. doi: 10.1590/0103-11042017s224

6. Alves HMC, Dourado LBR, Côrtes VNQ. A influência dos vínculos organizacionais na consolidação dos Centros de Atenção Psicossociais. Ciênc Saúde Colet. 2013;18(10):2965-75. doi: 10.1590/S1413-81232013001000021 
7. Salles MM, Barros S. Inclusão social de pessoas com transtornos mentais: a construção de redes sociais na vida cotidiana. Ciênc Saúde Colet. 2013;18(7):2129-38. doi: 10.1590/S1413-81232013000700028

8. Machado JC, Cotta RMM, Soares JB. Reflections on the process of municipalization of healthcare policies: the issue of political and administrative discontinuity. Interface (Botucatu). 2015;19(52):159-70. doi: 10.1590/1807-57622013.1002

9. Bardin L. Análise de conteúdo. 4ª ed. Lisboa: Edições 70; 2010.

10. Ministério da Saúde (BR). Resolução n 466, de 12 de dezembro de 2012. Dispõe sobre os direitos e deveres que dizem respeito aos participantes de pesquisa, à comunidade científica e ao Estado [Internet]. Brasília: Ministério da Saúde; 2012 [cited 2018 Feb 22]. Available from: http://bvsms.saude.gov.br/bvs/saudelegis/cns/2013/res0466_12_12_2012.html

11. Romanini $M$, Guareschi PA, Roso A. O conceito de acolhimento em ato: reflexões a partir dos encontros com usuários e profissionais da rede. Saúde Debate. 2017;41(113):486-99. doi: 10.1590/0103-1104201711311

12. Lussi IAO, Morato GG. O significado do trabalho para usuários de serviços de saúde mental inseridos em projetos de geração de renda vinculados ou não ao movimento da economia solidária. Cad Ter Ocup UFSCar. 2012;20(3):369-80. doi: 10.4322/cto.2012.037

13. Cardoso MRO, Oliveira PTR, Piani PPF. Práticas de cuidado em saúde mental na voz dos usuários de um Centro de Atenção Psicossocial do estado do Pará. Saúde Debate. 2016;40(109):86-99. doi: 10.1590/0103-1104201610907

14. Maynart WHC, Albuquerque MCS, Brêda MZ, Jorge JS. Qualified listening and embracement in psychosocial care. Acta Paul Enferm. 2014;27(4):300-4. doi: 10.1590/1982-0194201400051

15. Ministério da Saúde (BR). Portaria n 336, de 19 de fevereiro de 2002. Estabelece que os Centros de Atenção Psicossocial poderão constituirse nas seguintes modalidades de serviços: CAPS I, CAPS II e CAPS III, definidos por ordem crescente de porte/complexidade e abrangência populacional [Internet]. Brasília: Ministério da Saúde; 2002 [cited 2018 Feb 22]. Available from: http://bvsms.saude.gov.br/bvs/saudelegis/ gm/2002/prt0336_19_02_2002.html

16. Silva SN, Lima MG. Avaliação da estrutura dos Centros de Atenção Psicossocial da região do Médio Paraopeba, Minas Gerais. Epidemiol Serv Saúde. 2017;26(1):149-60. doi: 10.5123/s1679-49742017000100016

17. Eslabão AD, Coimbra VCC, Kantorski LP, Pinho LB, Santos EO. Mental health care network: the views of coordinators of the Family Health Strategy (FHS). Rev Gaúcha Enferm. 2017;38(1):e60973. doi: 10.1590/1983-1447.2017.01.60973

18. Almeida $A B$, Aciole GG. Gestão em rede e apoio institucional: caminhos na tessitura de redes em saúde mental no cenário regional do Sistema Único de Saúde (SUS). Interface (Botucatu). 2014;18(Suppl 1):971-81. doi: 10.1590/1807-57622013.0371

19. Onocko-Campos R, Furtado JP, Trapé TL, Emerich BF, Surjus LTLS. Evaluation Indicators for the Psychosocial Care Centers Type III: results of a participatory design. Saúde Debate. 2017;41(spe):71-83. doi: 10.1590/0103-11042017s07

20. Miranda L, Oliveira TFK, Santos CBT. Study of a Psychosocial Care Network: Paradoxes and effects of insecurity. Psicol Ciênc Prof. 2014;34(3):592-611. doi: 10.1590/1982-3703001662013

21. Prata NISS, Groisman D, Martins DA, Rabello ET, Mota FS, Jorge MA, et al. Saúde mental e atenção básica: território, violência e o desafio das abordagens psicossociais. Trab Educ Saúde. 2017;15(1):33-5. doi: 10.1590/1981-7746-sol00046 